\title{
Risk factors for communication disorders and complaints of preschoolers in a School Health Program
}

\author{
Naiara Mobiglia Benedicto ${ }^{1}$ \\ https://orcid.org/0000-0002-3051-1552 \\ Geise Caroline Marim ${ }^{1}$ \\ https://orcid.org/0000-0001-6861-4349 \\ Humberto de Oliveira Simoes ${ }^{1}$ \\ https://orcid.org/0000-0003-3544-8262 \\ Tatiane Martins Jorge ${ }^{1}$ \\ https://orcid.org/0000-0002-1017-6865
}

Universidade de São Paulo, Faculdade de Medicina de Ribeirão Preto, Departamento de Ciências da Saúde, Ribeirão Preto, São Paulo, Brasil.

Conflict of interests: Nonexistent

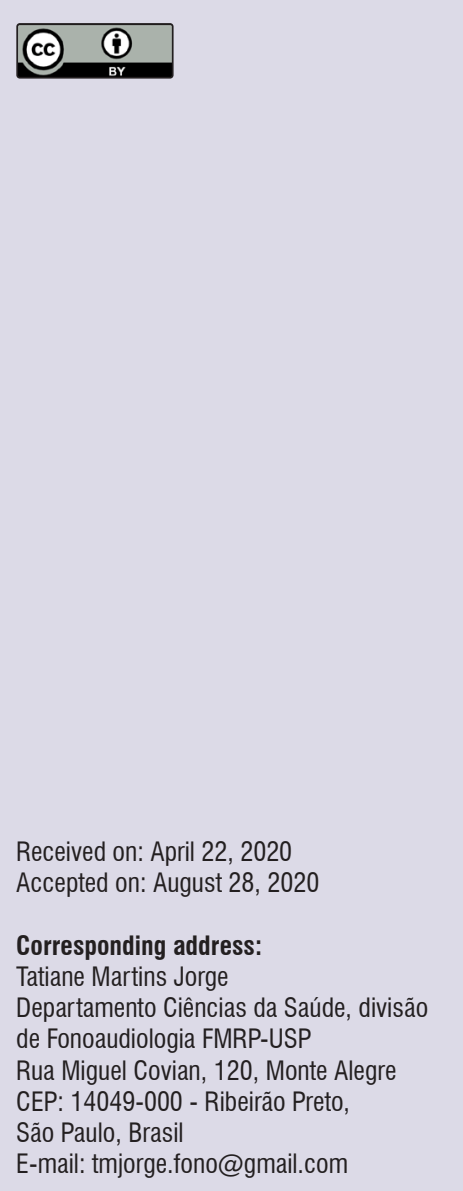

\section{ABSTRACT}

Purpose: to survey the prevalence of risk factors for communication disorders and complaints in preschoolers that participated in the School Health Program (SHP) and compare the findings with age and sex.

Methods: the sample comprised 190 preschoolers reached by the SHP. The collection procedure involved the exploration of data in questionnaires previously filled out by their relatives. The risk factors and communication complaints were presented in the occurrence frequency. The evidence of associations between variables was verified with the Mann-Whitney and chi-square tests, and the $5 \%$ significance level was used for all comparisons.

Results: baby bottle use was the most prevalent risk factor associated with age, being more frequent in younger children. The girls underwent more complications during pregnancy or birth and showed more nonnutritive sucking habits, whereas the boys had more hospital stays.

Conclusion: regarding the investigated risk factors, the baby bottle use was the most reported one, followed by ear infections or other ear problems. Complaints related to speaking and hearing were seldom mentioned, although those related to speaking occurred more frequently.

Keywords: Family Health Strategy; Public Health; School Health Services; Surveys and Questionnaires; Child, Preschool 


\section{INTRODUCTION}

The School Health Program (SHP) was created in Brazil by the Ministries of Health and Education in 2007 to develop cooperative actions between health and education. It is aimed at children, adolescents, and youth of the public education system, who are oftentimes vulnerable to circumstances that interfere with their wholesome development. The SHP actions are organized and carried out at schools by the centers that have an established Family Health Strategy (FHS) and by education professionals ${ }^{1}$. In the Sistema Único de Saúde (SUS, the Brazilian public health care system), the FHS, which was implemented to promote comprehensive health, is the gateway to primary health care ${ }^{2}$.

In the SHP, different types of actions take place including the screenings, which aim to obtain data and information on the schoolchildren's development. Regarding the communication aspects, the guidelines of the Ministry of Health only encompass initiatives to identify potential signs of hearing changes. The most current instrument (as of 2018) for the age group of preschoolers (children zero to five years old) indicated by the Sociedade Brasileira de Fonoaudiologia (Brazilian Speech-Language-Hearing Society), Associação Brasileira de Audiologia (Brazilian Audiology Society), and Conselho Federal de Fonoaudiologia (Federal Speech-Language-Hearing Council) ${ }^{3}$ recommends that the auditory and oral language development milestones be observed by the health professional, parents, and/or educators. For children older than six years, it suggests that questionnaires be used.

The focus on hearing problems is justified by the high rate of hearing changes in school age resulting from treatable secretory otitis media or cerumen impaction. Such changes influence both school achievement and hearing skills development, besides being potentially associated with language and behavior changes, and others. In case there is a suspicion for changes with a need for additional health care, the schoolchildren are referred to the community health center ${ }^{1}$.

Although the Ministry of Health suggests the investigation of auditory aspects only, it is useful to include other aspects of the student's communication because a high prevalence of communication disorders is particularly noticed in the phase from three to six years old ${ }^{4}$. Communication disorders are understood as the difficulties to pronounce sounds; stuttering; changes involving orofacial and cervical muscles and structures that affect the speech, breathing, chewing, swallowing, and sucking functions; problems with the voice; difficulties to read and write; besides the auditory problems ${ }^{5}$. These hindrances or difficulties can impair the quality of the person's relationship with their social environment ${ }^{6}$.

The speech-language-hearing therapist is one of the professionals in the health teams of the Sistema Único de Saúde (SUS), working in all health care levels. Thus, the SHP actions must broaden their investigation beyond the auditory issues since the health system can meet such needs. Early childhood - which is when the children are subject to greater interference from the environment - is an essential time to conduct multidisciplinary interventions aiming at the promotion of health and prevention of diseases and conditions ${ }^{7}$.

Communication-related screenings are restricted to the work of a speech-language-hearing therapist. However, administering questionnaires on communication complaints or risk factors for its development can be part of the routine of other professionals. Using questionnaires has many advantages, such as, for instance, saving time and human resources, simultaneously reaching a larger number of people, even from distant geographical areas, and ensuring safety and freedom to answer ${ }^{8}$.

The investigation must be based on scientific evidence for the approach to be truly effective ${ }^{2}$. Some questions, when positively answered, indicate that the children's communication development is at risk - e.g., being male, an only child, having a positive family history of communication disorders, complications during pregnancy, prematurity, and long postnatal hospital stays ${ }^{9}$. Regarding hearing, some questions are sensitive to identify auditory changes: "Does your child hear well?", and "Has he/she ever had ear infections or any other ear problems?". These questions have a positive relationship with the results of the otoacoustic emissions and tympanometry, which are clinical examinations sensitive to identify auditory problems ${ }^{10}$. 
This study is justified by the importance of having a broader view when dealing with possible changes in preschoolers. The usefulness of administering a questionnaire to this population lies also in its easy and low-cost application. Moreover, investigating and analyzing the prevalence of risk factors for, and complaints of, any type of oral communication change enables early and preventive actions to be planned. Hence, this study aimed to survey the prevalence of risk factors for communication disorders and complaints in preschoolers that participated in the SHP, comparing such findings with the participants' age and sex.

\section{METHODS}

This project was accepted by the Municipal Department of Health and a Family Health Center (FHC) in inland São Paulo, Brazil. Upon these institutions' consent, the project was forwarded for analysis by the Research Ethics Committee (REC) of the Teaching Health Center of the Faculdade de Medicina de Ribeirão Preto of the Universidade de São Paulo, SP, Brazil, which approved it (number 3.432.694; CAAE number 14808819.7.0000.5414).

This is a descriptive, cross-sectional, retrospective study with a quantitative approach. Its sample comprised 190 preschoolers who were reached by an SHP in 2018 conducted by a family health team in the municipality of Ribeirão Preto. To screen potential changes in the students' overall communication, this team, in partnership with an intern speech-languagehearing therapist of the Multiprofessional Internship Program, developed and administered a questionnaire to their parents and/or guardians.

The procedure in this study was to explore the collected data in the health center where the questionnaires were stored in files. Thus, the REC was solicited to exempt this study from providing an informed consent form, which was granted.

All the questionnaires filled out by those legally responsible for the children were included in the study, even if some of the questions had been left unanswered.

The questionnaires analyzed in the study had a total of 12 questions - one on demographic aspects (the child's age at the time when the questionnaire was answered), and 11 to investigate the student's communication. The questions encompassed both the risk factors for communication disorders - e.g., sex, a positive family history of communication disorders, prematurity, hospital stays, complications during pregnancy or birth, ear infections or other auditory problems, fail on the infant hearing screening test (Universal Neonatal Hearing Screening - UNHS), general health problems, nonnutritive sucking (pacifier or thumb), and baby bottle sucking - and communication complaints - e.g., the adults' difficulty to understand the child's attempts to communicate, and complaints related to sound detection.

The collected information was tabulated and quantitatively and blindly analyzed by two speech-languagehearing therapists experienced in primary health care.

The groups were compared regarding age with the Mann-Whitney test, a nonparametric technique that enables two independent groups to be compared without suppositions regarding the distribution of data. The comparisons involving the qualitative variables of interest and sex, besides prematurity with complications during pregnancy or birth and respiratory problems with an infection or other auditory problem, were performed with the chi-square test. All the analyses presented were carried out with the R software, version 3.4.1, and the $5 \%$ significance level was used for all the comparisons.

\section{RESULTS}

Regarding the prevalence of risk factors for communication disorders, Table 1 shows the number of questions answered and the number of affirmative answers for the factors mentioned. 
Table 1. Prevalence of risk factors (absolute number, followed by percentage) for communication disorders mentioned by the relatives in the School Health Program

\begin{tabular}{lcc}
\hline Questionnaire answer variable & $\begin{array}{c}\text { Number of questions } \\
\text { answered }\end{array}$ & $\begin{array}{c}\text { Number of affirmative } \\
\text { answers (\%) }\end{array}$ \\
\hline Male & 190 & $90(47.4)$ \\
Relatives with a history of communication disorders & 190 & $43(22.6)$ \\
Complications during pregnancy or birth* & 189 & $27(14.3)$ \\
Prematurity & 189 & $25(13.2)$ \\
Hospital stays & 188 & $49(26.1)$ \\
Health problems** & 189 & $27(14.3)$ \\
Nonnutritive sucking habit (thumb and/or pacifier) & 189 & $37(19.6)$ \\
Nutritive sucking habit (baby bottle) & 190 & $80(42.1)$ \\
Ear infections or other ear problems & 189 & $64(33.9)$ \\
Fail in the Infant Hearing Screening test & 135 & $16(11.8)$ \\
\hline
\end{tabular}

*The gestational complications most reported by the parents/guardians that answered the questionnaires were amniotic fluid and meconium aspiration, placenta displacement, arterial hypertension, pre-eclampsia, and bleeding.

${ }^{* *}$ Of the health problems, the most cited were the respiratory ones (63\%).

The prevalence of complaints related to the preschoolers' speaking and hearing, based on the number of questions answered and the number of affirmative answers, is described in Table 2.

Table 2. Prevalence of preschoolers' communication complaints (absolute number, followed by percentage) mentioned by the relatives in the School Health Program

\begin{tabular}{lcc}
\hline Questionnaire answer variable & Number of questions answered & Number of affirmative answers (\%) \\
\hline $\begin{array}{l}\text { The adults' difficulty to understand the } \\
\text { child's attempts to communicate }\end{array}$ & 190 & 7.4 \\
The child's difficulty to hear & 189 & 1.6 \\
\hline
\end{tabular}

The age of the preschoolers ranged from 39 months (three years and three months) to 79 months (six years and seven months) - the mean was 60 months, and the median, 61 . Concerning sex, $52.6 \%$ were females.

When analyzing the students' age (in months) in relation to the presence of complaints of and risk factors for communication disorders, a significant difference was found concerning the use of baby bottles ( $p=$ 0.02) (Table 3), with a lower mean age of those who used it.

In the comparison between the sexes, the females had more complications $(p=0.04)$ and pacifier and thumb-sucking habit $(p=0.02)$. The males, in their turn, had more hospital stays $(p<0.01)$ (Table 3$)$. 
Table 3. Comparative analysis of the answers furnished by the relatives, concerning age (in years) and sex

\begin{tabular}{lcc}
\hline \multirow{2}{*}{ Questions investigated } & \multicolumn{2}{c}{ Comparative variables } \\
\cline { 2 - 3 } & $\begin{array}{c}\text { Age } \\
\text { p-value }\end{array}$ & $\begin{array}{c}\text { Sex } \\
\text { p-value \#\# }\end{array}$ \\
\hline Family history of communication disorders & 0.25 & 0.24 \\
Complications during pregnancy or birth & 0.11 & $0.04^{*}$ \\
Prematurity & 0.98 & 0.18 \\
Hospital stays & 0.56 & $<0.01^{*}$ \\
General health problems & 0.41 & 0.59 \\
Respiratory problems & 0.92 & 0.61 \\
Nonnutritive sucking habit & 0.80 & $0.02^{*}$ \\
Baby bottle sucking habit & $0.02^{*}$ & 0.36 \\
Ear infections or other ear problems & 0.61 & 0.64 \\
Fail in the Infant Hearing Screening Test & 0.20 & 0.97 \\
Perception that the child hears well & 0.73 & 0.49 \\
People understand the child's attempt to speak & 0.75 & 0.45 \\
\hline
\end{tabular}

\#Mann-Whitney test; \#\#chi-square test; * ${ }^{*}$ significant p-value $<0.05$.

Another result that stood out was the relationship between prematurity and complications ( $p<0.01)$, according to the collected answers.

\section{DISCUSSION}

In both sexes, the communication disorders in childhood are more prevalent between three and six years old - i.e., in the preschool phase ${ }^{5,11}$ - which increases the demand for speech-language-hearing care during this period ${ }^{12}$. This points to the importance of screening communication, particularly of those in this age group.

Identifying communication disorders in the preschool phase allows for early interventions, decreasing the possibility of such problems affecting formal education and behavior ${ }^{13}$. Identifying children at risk of communication disorders when these are not yet present can make it easier to prevent them or improve future conditions ${ }^{14}$.

Some studies report that being male is a risk factor for communication disorders, as there are more boys than girls with this impairment ${ }^{5,11,12,15}$. In the present study, being male was associated with hospital stays as a risk factor, whereas being female was associated with complications during pregnancy or birth. The report of complications, in its turn, was associated with that of prematurity.

One of the risk factors for communication disorders is prematurity, which, in this study, was present in 13\% of the schoolchildren. Prematurity can predispose to various problems, such as the use of pacifiers and difficulties sucking ${ }^{16}$.

Another risk factor for communication, which was the most prevalent in this study, was baby bottle sucking (42.1\%). According to the literature, this habit is highly prevalent in childhood: nine out of 10 children used a baby bottle during infancy ${ }^{17}$. Such use tends to be more frequent in children whose mother works away from home ${ }^{18}$, which was not investigated in this study.

The habit of baby bottle sucking was more present in younger children, with a significant difference between the ages. This finding was also noted in another study, which verified a greater use of baby bottles around two years old, and a decrease in its use between two and five years old ${ }^{19}$.

Maintaining deleterious oral habits is associated with changes in muscle and skeletal development ${ }^{19}$, which consequently affects occlusion and the performance of speech and breathing functions ${ }^{20}$. Hence, actions aiming to identify preschoolers and provide guidance regarding the harm caused by these habits must be a multiprofessional initiative ${ }^{17,21}$, involving especially the primary health care professionals ${ }^{21}$.

Besides the importance of these actions in the SHP, the parents must be constantly instructed - beginning in prenatal care, in routine visits to the doctor, nurses, and/or dental surgeons - regarding the harm caused by early weaning and its relationship with starting and maintaining deleterious oral habits ${ }^{19}$. Encouraging breastfeeding is especially important since the 
prevalence of these habits decreases as the duration of breastfeeding increases ${ }^{19,22}$.

In the present study, pacifier and thumb sucking was significantly more prevalent among females, which was also noted in other studies ${ }^{17,23}$. However, explanations for this association require further qualitative investigations, particularly approaching the cultural and psychological influence of the sex on the habit of pacifier use ${ }^{17}$.

Ear infections or other ear problems were the most reported health conditions (33.9\%). Acute otitis media (AOM) has been described as one of the most frequent diseases in childhood and the main cause of visits to the doctor ${ }^{24}$. The actions in the SHP have focused on hearing, considering the impact of hearing problems on language development.

In this study, the positive family history of communication problems was mentioned by $22 \%$ of the parents. The presence of this risk factor makes it four times more likely for communication disorders to appear ${ }^{25,26}$, especially when they are first-degree relatives.

Also, as seen in Table 1, the results reveal that only $135(71 \%)$ out of the 190 adults legally responsible for the children answered the question on the infant hearing screening test. This is a quite worrying fact that calls for some reflection: Is it because the information in the result of the infant hearing screening test is not easily identified by all the parents? Or was the test not thoroughly filled out, raising doubts in the parents/guardians? In research on how the Personal Child Health Record is filled out ${ }^{27}$, it was observed that one of the least correctly filled in items was the result of the infant hearing screening test. Since 2010, the year before the children in this research were born, performing the said test has been mandatory in all maternities and hospitals, as provided in the Federal Law no. $12,303^{28}$.

The SHP preconizes the development of hearing health-promoting actions in all age groups. As for the preschoolers, though, the recommendation of the entities that represent the speech-language-hearing sciences $^{3}$, in 2018, was that the investigation be based on the observation of the auditory and language development milestones. The teams that do not count with a speech-language-hearing therapist in the health network probably have greater difficulties to carry out these actions. Hence the importance of having a speech-language-hearing professional in the Extended Family Health and Primary Care Center (NASF-AB, as abbreviated in Portuguese), as they are important cooperators in the team. They enrich the healthpromoting actions aimed at communication development and raise awareness in health professionals and educators for them to broaden their view beyond the hearing issues.

Moreover, it is necessary to standardize a questionnaire to guide the broad investigation of various aspects of communication or its risk factors, so that referrals can take place as early as possible. It would be particularly important to standardize a single questionnaire to be used in the SHP in all the states of the country, which would furnish more encompassing epidemiologic surveys. Further studies are suggested to relate the presence or absence of the said risk factors and communication complaints with the clinical findings of the assessment of all schoolchildren.

Given the scope of the SHP actions, which go beyond assessing the students' health status, the need for research that also describes the speech-languagehearing practices in health promotion and prevention is reinforced, as well as those related to the professional development of the educators. Some of the themes highlighted as a priority for these actions are food safety and healthy eating habits; body practices and physical activity at school; sexual health education; tobacco, alcohol, and other drugs prevention; peace culture and violence prevention; environmental health; and healthy development ${ }^{1}$.

\section{CONCLUSION}

Of the risk factors listed for this study, the most prevalent was the use of a baby bottle. Ear infections or other ear problems were the most reported health issues. There was also a considerable percentage of children with a history of hospital stays or family history of communication problems. Another datum that stood out was that a large portion of the parents did not know whether their children had been submitted to the infant hearing screening test.

Differences were noted regarding their sex and age in certain risk factors. The girls underwent more complications during pregnancy or birth and showed more nonnutritive sucking habits, whereas the boys had more hospital stays. The use of baby bottles was associated with age, being more prevalent among younger children. 


\section{REFERENCES}

1. Brasil. Ministério da Saúde. Secretaria de Atenção à Saúde. Departamento de Atenção Básica. Instrutivo PSE / Ministério da Saúde. Secretaria de Atenção à Saúde. Departamento de Atenção Básica. - Brasília: Ministério da Saúde, 2011.

2. Brasil. Ministério da Saúde. Secretaria de Atenção à Saúde. Departamento de atenção básica. Cadernos de Atenção Básica. Saúde na Escola. Brasília: Ministério da Saúde; 2009.

3. Sociedade Brasileira de Fonoaudiologia, Associação Brasileira de Audiologia e Conselho Federal de Fonoaudiologia. Instrumento para a realização de promoção da saúde auditiva e identificação de educandos com possíveis sinais de alteração auditiva. Sugestões finais: SBFa, ABA e CFFa. [cited 2020 Jan 29]. Available from: http://189.28.128.100/dab/docs/portaldab/ documentos/instrumento_saude_auditiva.pdf

4. Martins VO, Rodrigues A, Andrade RV, Andrade CRF, Lopes DMB, Fernandes FDM. Perfil epidemiológico dos distúrbios da comunicação humana atendidos em um ambulatório de Atenção Primária à Saúde. Rev Soc Bras Fonoaudiol. 2008:159-66. Anais. 2008; Available from: http:// www.sbfa.org.br/portal/anais2008/anais_select. php?op $=$ buscaresultado\&cid $=159 \&$ tid $=1$

5. Longo IA, Tupinelli GG, Hermógenes C, Ferreira LV, Molini-Avejonas DR. Prevalence of speech and language disorders in children in the western region of São Paulo. CoDAS. 2017;29(6):e20160036 DOI: 10.1590/2317-1782/20172016036

6. Goulart BNG, Chiari BM. Human communication and children health promotion - reflect on the actions of health promotion in childhood and prevention of communication disorders. Rev. CEFAC. 2012;14(4):691-6.

7. Matos GC, Santos JC, Guedes-Granzotti RB, Silva $\mathrm{K}$, Baldrighi SEZM, César CPHAR. The prevalence of oral habits in preschoolers. Distúrb. Comun. 2017;29(1):68-76.

8. Oliveira JCP, Oliveira AL, Morais FAM, Silva GM, Silva CNM. O questionário, o formulário e a entrevista como instrumentos de coleta de dados: vantagens e desvantagens do seu uso na pesquisa de campo em ciências humanas. III Congresso Nacional de Educação, 2016.

9. Silva GD, Couto MIV, Molini-Avejonas DR. Risk factors identification in children with speech disorders: pilot study. CoDAS. 2013;25(5):456-62.
10. Tamanini D, Ramos N, Dutra LV, Bassanesi HJC. School-age hearing screening: identification of hearing impairments in first-grade students. Rev. CEFAC. 2015;17(5):1403-14.

11. Keating D, Turrell G, Ozanne A. Childhood speech disorders: reported prevalence, comorbidity and socioeconomic profile. J Pediatr Child Health. 2001;37(5):431-6.

12. Hage SRV, Faiad LNV. Perfil de pacientes com alteração de linguagem atendidos na clínica de diagnóstico dos distúrbios da comunicação Universidade de São Paulo - Campus Bauru. Rev. CEFAC. 2005;7(4):433-40.

13. Wallace IF, Berkman ND, Watson LR, CoyneBeasley $\mathrm{T}$, Wood CT, Cullen $\mathrm{K}$ et al. Screening for speech and language delay in children 5 years old and younger: a systematic review. Pediatrics. 2015;136(2):e448-e462.

14. Stanton-Chapman TL, Chapman DA, Bainbridge NL, Scott KG. Identification of early risk factors for language impairment. Rev Dev Disabil. 2002;23(6):390-405.

15. Prates LPCS, Martins VO. Distúrbios da fala e da linguagem na infância. Revista Médica de Minas Gerais. 2011;21 (4 Supl 1):S54-S60.

16. Carcavalli L, Martins CC, Rocha IA, Parlato EM, Serra-Negra JM. Preterm birth, pacifier use and breastfeeding: is there a relationship? Braz Dent $\mathrm{J}$. 2018:29(4):388-94.

17. Ferreira FV, Senna RA, Ilha MC, Figueiró $P$, Feldens CA, Kramer PF. Uso de chupeta em pré-escolares do sul do Brasil: prevalência e fatores associados. RFO UPF. 2018;23(2):144-6.

18. Buccini GS, Benício MHD, Venancio SI. Determinants of using pacifier and bottle feeding. Rev Saúde Pública. 2014;48(4):571-82.

19. Pizzol KEDC, Montanha SS, Fazan ET, Boeck EM, Rastelli ANS. Prevalência dos hábitos de sucção não nutritiva e sua relação com a idade, gênero e tipo de aleitamento em pré-escolares da cidade de Araraquara. Rev. CEFAC. 2012;14(3):506-15.

20. Pereira TS, Oliveira F, Cardoso MCAF. Association between harmful oral habits and the structures and functions of the stomatognathic system: perception of parents/guardians. CoDAS. 2017;29(3):e20150301. 
21. Garbin CAS, Garbin AJl, Martins RJ, Souza NP, Moimaz SAS. Prevalência de hábitos de sucção não nutritivos em pré-escolares e a percepção dos pais sobre sua relação com maloclusões. Ciênc saúde coletiva. 2014;19(2):553-8.

22. Góes MPS, Araújo CMT, Góes PSA, Jamelli SR. Persistência de hábitos de sucção não nutritiva: prevalência e fatores associados. Rev Bras Saúde Matern Infant. 2013;13(3):247-57.

23. Miotto MHMB, Caxias FP, Campos DMKS, Ferreira LFPE, Barcellos LA. Breastfeeding as a protection factor to avoid non-nutritive sucking habits. Rev. CEFAC. 2014;16(1):244-51.

24. Sáfadi MAP, Jarovsky D. Acute otitis media in children: a vaccine-preventable disease? Braz J Otorhinolaryngol. 2017;83(3):241-2.

25. Mondal N, Bhat B, Plakkal N, Thulasingam M, Ajayan P, Rudhan R. Prevalence and risk factors of speech and language delay in children less than three years of age. J Compr Ped. 2016;7(2):e33173.

26. Sunderajan T, Kanhere SV. Speech and language delay in children: prevalence and risk factors. J Family Med Prim Care. 2019;8(5):1642-6.

27. Rossatto K, Lohmann PM. Caderneta de saúde da criança: análise da qualidade do preenchimento adequado. 2015. Artigo (Graduação) - Curso de Enfermagem, Universidade do Vale do Taquari Univates, Lajeado, 02 dez. 2015. Disponível em: http://hdl.handle.net/10737/2052.

28. Brasil 2010. Lei Federal $n=12.303$ de 2 de agosto de 2010. Lei do teste orelhinha. Dispõe sobre a obrigatoriedade de realização do exame denominado Emissões Otoacústicas Evocadas. Diário Oficial da União - Seção 1 - 3/8/2010, Página 1 (Publicação Original). 